\title{
Students' perceptions of a scientific writing course: SFL Genre Pedagogy in an EFL context
}

Percepções dos alunos sobre um curso de redação científica: Pedagogia de gênero da SFL em um contexto de

$E F L$

\section{Carolina Andrea Mirallas}

Universidade Nacional de San Luis - CONICET - San Luis - Argentina

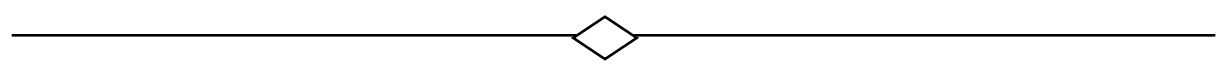

\begin{abstract}
Genre approaches to teaching have long been applied to improve students' skills, and their effect has usually been assessed by looking into students' productions. In this work, we examine students' perceptions of the implementation of a genre-based writing course that incorporated tasks developed by the Reading to Learn Pedagogy (R2LP) (ROSE; MARTIN, 2008) for the teaching of Scientific Research Articles (SRA) in an EFL context. A scientific writing course in English was offered for 8 weeks on a weekly basis to researchers and Ph.D. students in Argentina. They were asked to answer surveys after every class and once the course finished. Surveys were analysed considering Attitude of the System of Appraisal (MARTIN; WHITE, 2005), polarity and the entities evaluated. Joint writing and Detailed reading were entities frequently evaluated positively, mainly in terms of usefulness. Negatively appraised entities include contents and exercises, which were perceived as "difficult". Our evidence suggests that the teaching of SRA writing to researchers through the R2LP in an EFL context is effective. More precisely, teacher-guided activities which were jointly carried out with students were found to be the most useful, making them suitable for a highly specialised audience like the one that participated in this study.
\end{abstract}

Keywords: Specialist Informants; Scientific Research Article; System of Appraisal; entities; scientific writing.

Resumo: As abordagens de gênero para o ensino têm sido aplicadas há muito tempo para melhorar as habilidades dos alunos, e seu efeito geralmente foi avaliado olhando para as produções dos alunos. Neste trabalho, examinamos as percepções dos alunos sobre a implementação de um curso de redação baseado em gênero que incorporou tarefas desenvolvidas pela Pedagogia Ler para Aprender (LPA) (ROSE; MARTIN, 2008) para o ensino de Artigos de Pesquisa Científica (APC) em um contexto de EFL. Um curso de redação científica em inglês foi oferecido por 8 semanas para pesquisadores e estudantes de doutorado na Argentina. Eles responderam pesquisas após cada aula e ao término do curso. As pesquisas foram analisadas considerando a Atitude do Sistema de Avaliação (MARTIN; WHITE, 2005), a polaridade e as entidades avaliadas. A redação conjunta e a leitura detalhada foram entidades frequentemente avaliadas positivamente, principalmente em termos de utilidade. Entidades avaliadas negativamente incluem conteúdos e exercícios que foram percebidos como "difíceis". Nossas evidências sugerem que o ensino da escrita de APC para pesquisadores por meio do LPA em um contexto de EFL é eficaz. Mais precisamente, as atividades orientadas pelo professor e realizadas em conjunto com os alunos revelaram-se as mais úteis, tornando-as adequadas a um público altamente especializado como o que participou neste estudo.

Palavras-chave: Informantes Especialistas; Artigo de Pesquisa Científica; Sistema de Avaliação; entidades; escrita científica. 


\section{Introduction}

For the last forty years, genre, genre pedagogy, and literacy have received increasing attention (HYON, 1996; HYLAND, 2003). Research carried out on authentic texts has informed genre approaches and theories of language and teaching from a social and situated perspective. Although the differences among genre traditions have become less sharp, as observed by Hyland (2003) and Swales (2009), it is possible to distinguish some features. While the New Rhetoric has focused on the situational contexts in which SRA occurs, the English for Specific Purposes (ESP) school has paid attention to detailing SRA formal characteristics of organizational patterns. The Systemic Functional Linguistics genre tradition known as the Sydney School- shares much common ground with ESP and the New Rhetoric genre research, mainly the social world, academic and professional fields of interaction, and notions of context. However, a distinction can be made in connection to the wellgrounded, thoroughly detailed, and sound pedagogy for the teaching of genres that the Sydney School has developed (DEREWIANKA; JONES, 2012; ROSE; MARTIN, 2012; ROTHERY, 1989, 1996), as well as its commitment to language and literacy education.

Genre traditions have largely focused, nonetheless, on English as a first or second language in contexts where it is spoken for daily communication. The growing impact that the genre movement has had around the world has called for research on genre pedagogies in more specific environments of English as a foreign language (MANCHÓN; DE HAAN 2008). This study addresses this issue by analysing students' perceptions of a genre-based scientific writing course in EFL, as it incorporated tasks described by the Reading to Learn Pedagogy (heretofore R2LP) (HALLIDAY; MARTIN, 1993; MARTIN, 2009; ROSE; MARTIN, 2012), within the framework of Systemic Functional Linguistics (SFL) (HALLIDAY, 1978; HALLIDAY; MATTHIESSEN, 2014), which has received less attention than the other approaches to genre.

Much research has been carried out on teachers' and students' perceptions of teaching methodologies and class dynamics (BITCHENER; BASTURKMEN, 2006; SHEHADEH, 2011; STORCH, 2005). Students' views are of particular interest because it is possible to describe their attitudes and experiences first hand from users' perspectives. Except for some studies carried out in the Latin American context at secondary schools (SILVA, 2019) and at undergraduate ESP courses (CAVALCANTI, 2016), to our knowledge, no research has assessed the R2LP from the perspective of adult students in the context of postgraduate courses. Moreover, the students that participated in this study are researchers, and their opinion on a teaching pedagogy is valuable for a number of reasons. First, they may be considered to be "specialist informants" (SELINKER, 1979) as they are well aware of particular needs when writing science in English. They are also expert readers in their fields so they are competent to identify what language is appropriate in their areas and what patterns of language are recurrent for highly specific uses. Finally, and most importantly, they have all gone through different experiences, both for their disciplinary education and their foreign language learning, which makes them eligible to assess a particular pedagogy for the teaching of writing SRA.

In this work, we present students' reactions to what Tardy (2006) defines as an "instruction based study"; i.e. research which explores a specific teaching approach within a classroom (p. 82). We explore students' perceptions of a writing course which implemented the R2LP for the teaching of writing scientific texts in English as a foreign language to Argentinian university researchers and Ph.D. students. We implement Attitude of the system of Appraisal to analyse the discourse that they produced in surveys in order to identify the entities that they assess.

\section{Theoretical Framework}

\subsection{SFL: On scientific discourse and the SRA}

Scientific discourse has been largely characterised from an SFL perspective (HALLIDAY; MARTIN, 1993; LEMKE, 1990; 1998; MARTIN, 1989; 1998; ROSE, 1998, WIGNELL, 1997, to name just a few), and the SRA has been defined as a macro-genre 
(HOOD, 2010; MARTIN; ROSE, 2008). It is understood as an interlocking set of genres which operate with an over-riding social purpose (MARTIN, 1992) whose aim is to facilitate the control of the natural world. Due to the undebatable importance that SRA has in the communication of knowledge, this is the genre under focus in the course we offered.

\subsection{The Sydney School: Reading to Learn Pedagogy}

The Sydney School refers to the work of teachers and researchers around the world in language and education whose aim has been "providing learners with explicit knowledge about the language in which the curriculum is written and negotiated in the classroom" (ROSE; MARTIN 2012, p. 2). It has been thoroughly informed by SFL and the sociological perspective of Basil Bernstein, and widely applied in a variety of contexts such as primary (BRISK, 2014; CHRISTIE, 2012; DE OLIVEIRA; LAN, 2014; TROYAN, 2016), secondary (HUMPHREY; MACNAUGHT, 2016; RAMOS, 2014) and higher education (HUMPHREY; MACNAUGHT, 2011; HUANG, 2014).

Although several strands of SFL Pedagogies (DEREWIANKA; JONES, 2012; ROSE; MARTIN, 2012; ROTHERY, 1989, 1996) and didactic designs have been proposed, in this work we have deployed the tasks described by the Reading to Learn Pedagogy. R2LP has been characterised as a set of strategies for the explicit teaching of reading and writing in classrooms at all levels of education (ROSE; MARTIN, 2012, p. 147). Activities have been carried out in reading-oriented tasks such as Preparing for Reading, Detailed Reading and Sentence Making. In these, there is an explicit emphasis on building field understanding and text analysis in order to provide students with maximum support. For writing tasks -Joint construction, Joint Rewriting and Spelling-, the teacher guides the class to write a new text and plays a central leading and highly interventionist role (MARTIN, 1999). In Individual Construction, Individual Rewriting and Sentence Writing, students write their own texts. For further details on the R2LP, we refer the reader to Rose and Martin (2012).

Regional studies in Latin America have also implemented SFL Pedagogies for the teaching of oral and written skills (see, for example BRAGA, 2019; HERAZO RIVERA; SAGRE BARBOZA, 2016, MOYANO, 2005, 2007, 2013, 2018). These studies have been carried out in local contexts, with Spanish and Portuguese as first languages. Few efforts, however, have been carried out for the teaching of scientific writing in English as a foreign language (MIRALLAS, forthcoming). This work reports on students' perceptions about a specific teaching intervention in EFL for the writing of SRA.

\subsection{Research on scientific genres that informed the contents of the course}

As previously mentioned, the course was taught with the R2LP as the theoretical foundation for the pedagogical intervention. In addition, it was informed by the vast rhetoric and linguistic descriptions of scientific texts available in current literature. Rhetorical descriptions of stages in SRA include titles (HAGGAN, 2004; SOLER, 2011), the abstract (HYLAND; TSE, 2005; SALAGER-MEYER, 1992; SAMRAJ, 2005), introductions (BHATIA, 1997; HOOD, 2010; SAMRAJ, 2005; SWALES, 1990), methods (LIM, 2017), results (BRUCE, 2009; THOMPSON, 1993; WILLIAMS, 1999), discussion (HOLMES, 1997, HOPKINS; DUDLEY-Evans, 1988; PARKINSON, 2011) and conclusions (RUIYING; ALLISON, 2003).

Research on lexicogrammatical aspects were also presented for verb tenses (SALAGER-MEYER, 1992), impersonality (MARTíNEZ, 2001), passive voice (ESPINOZA, 1997) and report verbs (HYLAND, 1999). Finally, findings on interpersonal meanings (HOOD, 2010; HOOD; MARTIN, 2005; HYLAND; TSE, 2005) and the principles of intertextuality (BAKHTIN, 1981; KRISTEVA, 1980) were also incorporated. 


\subsection{The System of Appraisal as data analysis framework}

We relied on the system of Appraisal as the theoretical framework that guided the analytical process for the surveys. The System of Appraisal is located at the discourse semantics level (MARTIN; WHITE, 2005) and it describes interpersonal and evaluative language. It is described by Martin and White (2005, p. 35) as follows (author's emphasis):

The System of Appraisal is regionalised as three interacting domains - 'attitude', 'engagement' and 'graduation'. Attitude is concerned with our feelings, including emotional reactions, judgments of behaviour and evaluation of things. Engagement deals with sourcing attitudes and the play of voices around opinions in discourse. Graduation attends to grading phenomena whereby feelings are amplified and categories blurred.

Resources that express evaluation in the Appraisal framework are not restricted to typical lexical word categories associated with evaluation such as adjectives, but also included are nouns, verbs and adverbs, as well as grammatical resources such as mood choice (MARTIN; WHITE, 2005). It is precisely this that serves for a thorough detection of evaluation in texts, as it was intended in this work.

Appraisal has been extensively used as theoretical as well as analytical framework for discourse research in English (BEDNAREK, 2008; HOOD, 2006; WHITE, 1998 among many others), for which it was developed, as well as in Spanish, in a variety of texts (GONZÁLEZ RODRÍGUEZ, 2011; HOOD; MARTIN, 2005; OTEÍZA; PINUER, 2012; PASCUAL, 2014, 2017, 2019; HERRERO RIVAS, 2017). Except for a few studies (BALLARD, BECKER; SMITH, 2017; HUFFMAN, 2015, SAN MARTíN, HELALE; FALETTI, 2012, SILVA, 2019), descriptions of response texts under the light of Appraisal are not abundant. In this study, we describe the assessment that students made of a R2LP-based writing course, and resorted to Attitude (CAVALCANTI, 2016; SILVA, 2019) since it is particularly relevant to our aim, for it describes feelings, emotions, judgements and appreciations of people and things (MARTIN; WHITE, 2005, p. 35).

\section{Instruction of the course for scientific writing}

\subsection{Context}

In English-speaking contexts, English for Academic or Specific Purposes is usually a compulsory course at most universities (WINGATE, 2012), and students need to pass it at the beginning of their training (CARLINO; 2004). The situation is rather different in South America, and more precisely, in Argentina. Universities do not usually offer explicit and/or specific writing instructions for students in their mother tongue (CARLINO, 2010). The situation becomes even more critical when it comes to a foreign language such as English (MARTíNEZ, 2011). Most academic literacy trainings in undergraduate programs in Argentina are restricted to reading technical texts in foreign languages (BANEGAS, 2018). Because of these limitations, researchers and Ph.D. students who attended our course had received little or no training in academic and scientific writing in a foreign language, as reported in a survey they filled in before the course (see supplementary data). Their previous learning experience had been in general English, mainly in language academies and/or with private teachers. Their scientific writing experience was through informal practices, in collaboration with colleagues or through individual efforts.

Students reported to have an intermediate level of English. All of them participated in research activities and had a part-time or full-time job at university. Although previous experience in writing was not a requirement to attend the course, most students mentioned having published complete SRA or segments of this genre, abstracts for congresses and reports in English. Fourteen students finished the whole course, and the group was composed of Electronic and Chemical Engineers, Geologists, Physicists and Bachelors in Computer Sciences. Most of them held Specialization, Masters or Ph.D. degrees. 


\subsection{Implementation of the R2LP}

A 60-hour course on scientific writing was taught on the basis of a weekly meeting for eight weeks at a state university in Argentina. The main objective of the course was to help students produce SRA adequate for an international community. Students were offered a variety of contents, ranging from the contextualization of scientific genres to linguistic features typical of the sections of the SRA. Instructors were all teachers or translators of English with postgraduate studies and research experience in scientific genres.

Students were told about our research objectives, filled in an informed consent on the use of their answers for our investigation and were told that some activities would follow the principles of a specific methodology (R2LP) that would be evaluated for research purposes. Lessons were instructed in Spanish, while all materials were in English. All students shared the same mother tongue (MARTíNEZ, 2011), and although they were used to reading and writing in English, their oral skills were weaker. Thus, using English as the means for instruction would have posed an unnecessary barrier for students to understand and participate in the course.

The R2LP proposes strategies to be carried out in the classroom for the teaching of story, factual and argumentative texts (ROSE; MARTIN, 2012). Although at first sight it might seem appropriate to deploy those for factual texts -due to the straightforward connection that the SRA has with explanations (ROSE; MARTIN, 2012, p. 128)-, the set of strategies selected for the course was the one developed for story genres (ROSE; MARTIN, 2012, p. 148). On the other hand, activities for factual text emphasise reading to learn about the field knowledge about which students need to write. Clearly, this was not the need that our students brought to class. Actually, they were experts in their own disciplines, and there was little that language teachers could offer them in this sense. Strategies developed for story texts, on the other hand, appeared to be more suitable. Our audience, rather, needed to learn about elaborate language patterns, as described in strategies for writing stories (ROSE; MARTIN, 2012, p. 162). Additionally, the ultimate aim of story writers is to engage readers, one of the main purposes of the abstract and the SRA (HYLAND; TSE, 2005; SWALES, 1990).

Since the teaching sequence of the R2LP is quite time-consuming (see SILVA, 2019, p. 139 for a similar appreciation) and pays special attention to students' comprehension of texts and to text production, the complete cycle was thoroughly carried out in the teaching of the title and the introduction. Only some tasks proposed by this pedagogy were implemented for the other sections of the course, as summarised in Table 1 . It is worth mentioning that students were asked to collect small corpora of 10 SRA of their disciplines in order to resort to them for observation.

\begin{tabular}{|c|c|c|c|}
\hline $\begin{array}{c}\text { RA } \\
\text { component }\end{array}$ & $\begin{array}{c}\mathbf{R 2 L} \\
\text { strategies }\end{array}$ & Activities & $\begin{array}{c}\text { Language } \\
\text { content and } \\
\text { contextual } \\
\text { features at stake }\end{array}$ \\
\hline \multirow[t]{3}{*}{ Title } & $\begin{array}{l}\text { Preparing } \\
\text { for reading }\end{array}$ & $\begin{array}{l}\text { Students and } \\
\text { teachers } \\
\text { discussed the } \\
\text { importance of } \\
\text { a good title. } \\
\text { Students and } \\
\text { teachers } \\
\text { identified } \\
\text { grammatical } \\
\text { forms and } \\
\text { analysed } \\
\text { meanings of a } \\
\text { sample title } \\
\text { and in titles } \\
\text { taken from } \\
\text { students' } \\
\text { corpora. } \\
\text { Students and } \\
\text { teachers } \\
\text { compared and } \\
\text { contrasted the } \\
\text { experiential } \\
\text { meanings } \\
\text { frequently } \\
\text { realised in } \\
\text { titles in } \\
\text { different } \\
\text { disciplines. }\end{array}$ & $\begin{array}{l}\text { Forms that titles } \\
\text { may adopt: } \\
\text { nominalisation, } \\
\text { compound } \\
\text { nominalisations or } \\
\text { sentences. } \\
\text { Building on field: } \\
\text { identifying } \\
\text { experiential } \\
\text { meanings } \\
\text { frequently } \\
\text { expressed in the } \\
\text { titles of the } \\
\text { disciplines of the } \\
\text { students (see } \\
\text { Author, in press). }\end{array}$ \\
\hline & $\begin{array}{l}\text { Joint } \\
\text { construction } \\
\text { \& Joint } \\
\text { rewriting }\end{array}$ & $\begin{array}{l}\text { Teachers and } \\
\text { students wrote } \\
\text { a title on the } \\
\text { board about } \\
\text { the } \\
\text { investigation } \\
\text { of one of the } \\
\text { students. }\end{array}$ & \\
\hline & $\begin{array}{l}\text { Individual } \\
\text { construction }\end{array}$ & $\begin{array}{l}\text { Students } \\
\text { wrote a title of } \\
\text { their own at } \\
\text { home. }\end{array}$ & \\
\hline Introduction & $\begin{array}{l}\text { Preparing } \\
\text { for reading }\end{array}$ & $\begin{array}{l}\text { Teachers and } \\
\text { students } \\
\text { discussed the } \\
\text { importance of } \\
\text { introductions, } \\
\text { the type of } \\
\text { information } \\
\text { they include } \\
\text { and what their }\end{array}$ & $\begin{array}{l}\text { Frequently used } \\
\text { language that } \\
\text { expresses } \\
\text { generality as the } \\
\text { common grounds } \\
\text { of a discipline, a } \\
\text { void in research, } \\
\text { negative } \\
\text { meanings, counter }\end{array}$ \\
\hline
\end{tabular}




\begin{tabular}{|c|c|c|c|}
\hline & $\begin{array}{l}\text { Detailed } \\
\text { reading }\end{array}$ & $\begin{array}{l}\text { rhetorical } \\
\text { purposes are } \\
\text { (Hood, 2010; } \\
\text { Swales, } \\
\text { 1990). } \\
\text { Students } \\
\text { highlighted } \\
\text { phrases in } \\
\text { printed copies } \\
\text { of } \\
\text { introductions } \\
\text { which } \\
\text { expressed the } \\
\text { argumentative } \\
\text { purposes of } \\
\text { the writer. } \\
\text { Students and } \\
\text { teachers } \\
\text { discussed the } \\
\text { meanings } \\
\text { expressed by } \\
\text { the phrases } \\
\text { identified. }\end{array}$ & $\begin{array}{l}\text { expectations, and } \\
\text { the objective of the } \\
\text { work. } \\
\text { Resources to } \\
\text { express } \\
\text { intertextuality. }\end{array}$ \\
\hline & $\begin{array}{c}\text { Joint } \\
\text { construction } \\
\text { \& Joint } \\
\text { rewriting }\end{array}$ & $\begin{array}{l}\text { Students and } \\
\text { teachers } \\
\text { thought of a } \\
\text { topic that } \\
\text { everyone } \\
\text { could } \\
\text { contribute to, } \\
\text { and wrote an } \\
\text { introduction } \\
\text { that } \\
\text { established } \\
\text { the need to } \\
\text { synchronize } \\
\text { traffic lights in } \\
\text { the city. } \\
\text { Students } \\
\text { contributed } \\
\text { with ideas at } \\
\text { the same time } \\
\text { that one of the } \\
\text { teachers } \\
\text { typed on a } \\
\text { computer, and } \\
\text { the text was } \\
\text { projected on a } \\
\text { screen for } \\
\text { everybody to } \\
\text { see. Another } \\
\text { teacher } \\
\text { guided and } \\
\text { organised } \\
\text { students' } \\
\text { comments. } \\
\text { Teachers and } \\
\text { students re- } \\
\text { read the } \\
\text { production } \\
\text { and improved } \\
\text { wordings. }\end{array}$ & \\
\hline & $\begin{array}{l}\text { Individual } \\
\text { construction }\end{array}$ & $\begin{array}{l}\text { Students were } \\
\text { asked to } \\
\text { produce an } \\
\text { introduction of } \\
\text { their own or } \\
\text { improve one } \\
\text { they had } \\
\text { written before. }\end{array}$ & \\
\hline \multirow[b]{2}{*}{$\begin{array}{l}\text { Methodology } \\
\text { Results } \\
\text { Discussion } \\
\text { Conclusion }\end{array}$} & $\begin{array}{l}\text { Preparing } \\
\text { for reading }\end{array}$ & $\begin{array}{l}\text { Teachers and } \\
\text { students } \\
\text { discussed the } \\
\text { purposes that } \\
\text { are carried out } \\
\text { by each of the } \\
\text { sections. }\end{array}$ & \multirow[t]{2}{*}{$\begin{array}{l}\text { Impersonality, } \\
\text { interpersonal } \\
\text { meanings, } \\
\text { comparatives and } \\
\text { superlatives, } \\
\text { intertextuality. }\end{array}$} \\
\hline & $\begin{array}{l}\text { Detailed } \\
\text { reading }\end{array}$ & $\begin{array}{l}\text { Sample } \\
\text { sections } \\
\text { provided by } \\
\text { teachers or } \\
\text { sections taken } \\
\text { from students' } \\
\text { corpora were } \\
\text { read to } \\
\text { identify and } \\
\text { highlight } \\
\text { linguistic } \\
\text { elements }\end{array}$ & \\
\hline
\end{tabular}

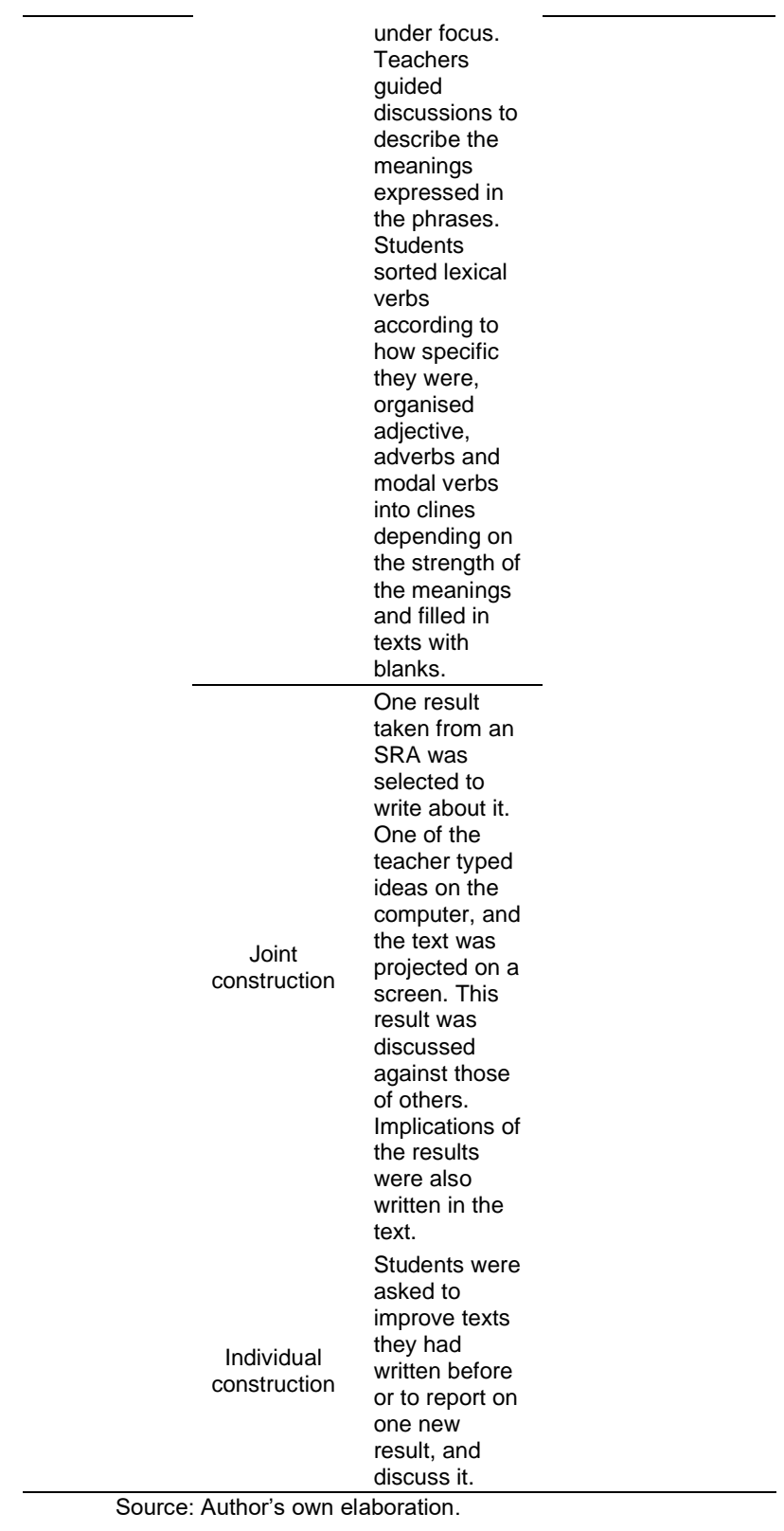

4. Methodology Collection and analysis of students' perceptions

Students' perceptions were collected at two distinct moments: after every class (class surveys, Corpus A) and after the course ended (end-of-course surveys, Corpus B). Class surveys contained openended questions, while end-of-course surveys contained open-ended as well as multiple choice questions (see supplementary data). In order to qualitatively describe students' discourse about the course, only open-ended questions were analysed for this work. Corpus A was composed of 151 surveys, with a total of 662 answers, and Corpus $B$ was made up of 14 surveys, with 109 answers. It is important to 
mention that both surveys were completed in Spanish (see SHEHADEH [2011] on some drawbacks of using the foreign language to collect data on students' perceptions). Spanish was preferred because students may not have had the necessary lexicogrammatical resources in English to produce the opinions required for this research. Additionally, it should be stated that students assessed the classes and course as a whole, and there was no special focus in the questions on the R2LP in particular.

Annotations were carried out with the UAM CorpusTool (O'DONNELL, 2008) (Fig. 1) which involved Attitude, Polarity, and entities, understood as the semiotic object in the real world that is appraised. This last category has been previously considered for scientific texts (THETELA, 1997), and it has specifically been used here to refer to components of the class that students assessed, and the system was developed as categories emerged in students' responses.

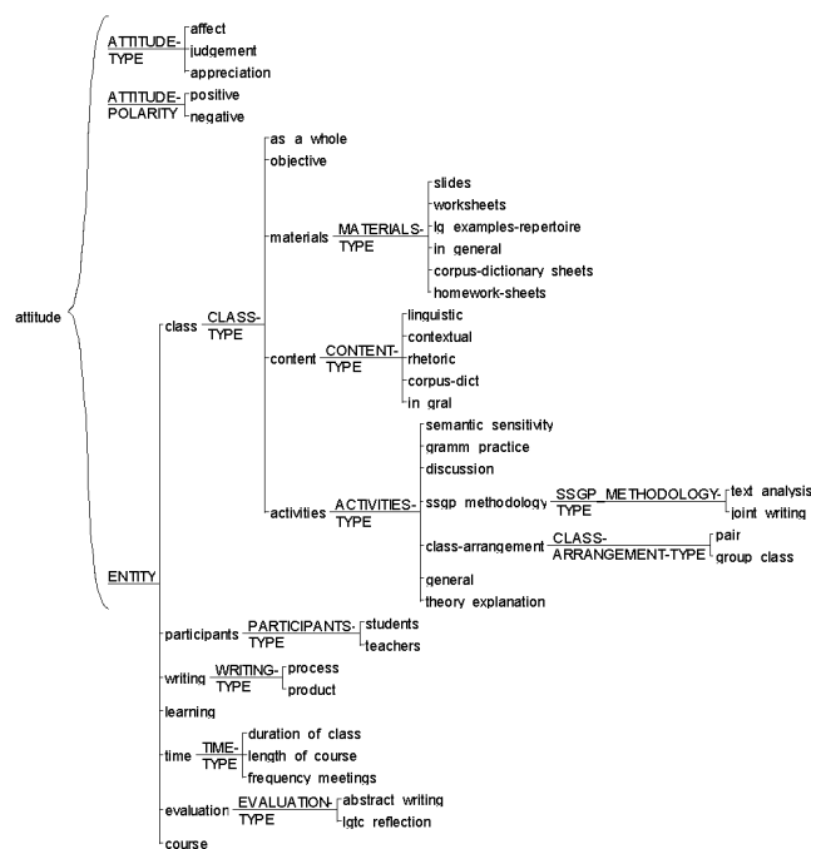

Fig. 1 System of Attitude and Entities used in the analysis of students' surveys

Source: Author's own elaboration. System designed in UAM CorpusTool.

All lexicogrammatical elements expressing Attitude were identified and subclassified according to subsystems (Affect, Judgment and Appreciation) and according to their polarity (positive or negative). In addition, world entities to which the appraising elements referred were also identified (HOOD, 2010; THETELA, 1997). For example, in the case of a question like "What activity can be improved?", "activity" is the world object, and "can be improved" is the appraising element. Once identified, entities were classified according to emerging categories.

There were two main types of questions in the surveys. The first ones include questions like [1] ${ }^{1}$, which contained an appraising element in their framing ${ }^{2}$.

[1]Question: Revise las tareas llevadas a cabo durante esta clase. ¿Qué actividad/es le resultó/resultaron útil/es? ¿Por qué?

Answer: [CA. St7. Q2. C1.] En general las diferentes discusiones que se dieron durante la clase.

Question: Check the tasks carried out during this lesson. Which ones were useful? Why?

Answer: In general the different discussions that were generated in the lesson.

In this case, "útil/es" (useful) [ATTITUdE: Appreciation: Valuation] appraises the entity "discusiones" (discussions). In the second type of question [2], no appraising element was included in the question. Therefore, the evaluative element was provided by students in answers.

[2] Question: Por favor, consigne otros comentarios que no estén contemplados en esta hoja.

Answer: [CA. St19. Q8. C1.] Me pareció muy buena e interesante la clase.

Question: Please, provide any other comments that were not considered in this sheet.

Answer: I thought the lesson was very good and interesting.

In [2], "buena" (good) and "interesante" (interesting) are the appraising elements that the student used to assess "la clase" (the class).

\section{Results and discussion}

The findings are presented in terms of the polarity of the evaluation, i.e., whether students assessed entities negatively or positively, and the entity referred to. We discuss in detail those which are more recurrent in students' discourse and resort to students' answers to give voice to their perceptions about the 
course. While 243 entities were assessed negatively, 696 entities were evaluated positively.

\subsection{Negative assessment}

Entities that have been appraised negatively in students' discourse are the Lesson (125 mentions, $51.5 \%)$, Participants (53, 22\%), Time (42, 17\%), Writing (8, 3\%), the Evaluation (13, 5\%) and the Course as a whole (2, 1\%). Table 2 shows these entities in further detail.

Table 2. Entities appraised negatively

\begin{tabular}{|c|c|c|c|c|}
\hline \multicolumn{2}{|c|}{ Entity } & $\begin{array}{l}\text { Class } \\
\text { surveys }\end{array}$ & $\begin{array}{l}\text { End-of- } \\
\text { course } \\
\text { surveys }\end{array}$ & Total \\
\hline \multirow{5}{*}{ Lesson } & Contents & 59 & 3 & 62 \\
\hline & Activities & 35 & 3 & 38 \\
\hline & Materials & 21 & 3 & 24 \\
\hline & As a whole & 1 & & 1 \\
\hline & Total & 116 & 9 & 125 \\
\hline \multirow{3}{*}{ Participants } & Students & 22 & 18 & 40 \\
\hline & Teachers & 7 & 6 & 13 \\
\hline & Total & 29 & 24 & 53 \\
\hline \multirow{4}{*}{ Time } & $\begin{array}{l}\text { Duration of } \\
\text { the lessons }\end{array}$ & 12 & 18 & 30 \\
\hline & $\begin{array}{l}\text { Frequency of } \\
\text { meetings }\end{array}$ & & 6 & 6 \\
\hline & $\begin{array}{l}\text { Length of } \\
\text { course }\end{array}$ & 3 & 3 & 6 \\
\hline & Total & 15 & 27 & 42 \\
\hline \multirow{3}{*}{ Writing } & Process & 3 & 1 & 4 \\
\hline & Product & 1 & 3 & 4 \\
\hline & Total & 4 & 4 & 8 \\
\hline Evaluation & Total & & 13 & 13 \\
\hline Course & Total & 2 & & 2 \\
\hline \multicolumn{2}{|c|}{ Total } & 166 & 77 & 243 \\
\hline
\end{tabular}

The Lesson is the most frequently assessed entity, which includes Contents (62 instances, which represents $50 \%$ of the Lesson), Activities (38, 30\%), Materials $(24,19 \%)$ and the Lesson (1, 1\%).

[3] [CA. St16. Q4. C3.] [Una dificultad con la que me encontré hoy es] Elección de tiempos verbales cuando es posible más de uno.
[A difficulty I came across today was] the selection of verb tenses when there is more than one possibility.

In [3], the student mentions his difficulty in selecting the right tenses. In line with Silva's (2019) findings related to students' perceived difficulty of language content, many were the students who, similarly to this one, considered linguistic contents such as vocabulary and grammar to be "difficult". This may be connected to the fact that they were attending a course of writing in English, which is a foreign language to them, and it is precisely this what they needed to acquire to write about their fields.

As for Activities, Grammar practice was frequently assessed as hard.

[4][CA. St19. Q4. C3.] Recordar la voz pasiva. Identificar los núcleos en los títulos de mi disciplina.

Remembering the passive voice. Identifying the nuclei of titles in my discipline.

In [4], the student refers to a passive voice exercise and to the identification of constituents in nominalisations when analysing titles. Although both exercises were solved with classmates and teachers, these definitely represent a challenge for students.

In connection to the assessment of the R2LP, only one perception which may be related to this methodology was negative [5].

[5][CA. St1. Q7. C1]. El intercambio de ideas en ocasiones se vuelve confuso 0 distractivo.

The exchange of ideas was sometimes confusing or distractive.

In this case, although an R2LP activity is not specifically referred to by the student, we may understand that the discussion and brainstorming carried out for Detailed reading seemed rather chaotic. Although this may be an individual perception, it might be interpreted as her need to be part of an even more organised and sequenced lesson.

Another entity which was assessed negatively was "Participants", for both Students $(40,16.5 \%)$ and Teachers $(13,5 \%)$. In the case of Students, they usually thought that they did not have enough 
grammatical or lexical knowledge [6] or that they needed to become more involved in the lesson [7].

[6][CA. St22. Q4. C8.] Las dificultades son propias de mi nivel de inglés que no me permite aún tener claras algunas cosas.

The difficulties that are typical of my level of English which does not allow me to have some things clear.

[7][CA. St22. Q7. C3.] Debo mejorar mi participación.

I have to improve my participation.

Students were critical of many aspects of the course, including themselves. They assessed both their knowledge and skills with English (SILVA, 2019), as well as their own doings. They were aware of the fact that their participation in class was a key factor in learning. Supporting adult students in connection to language seems to be very important, even when they are experts in their own disciplines.

In the case of Teachers, negative evaluations included the speed of delivery of the lesson [8] or how much time they devoted to some activities [9].

[8][CA. St20. Q4. C3.] [Una de las dificultades es] Velocidad de la clase. Un poco rápido.

[One of the difficulties is] The speed of the lesson. A bit fast.

[9][CA. St28. Q7. C1.] Se podría realizar la clase en forma más acotada al introducir los conceptos y no extenderse tanto en los comentarios de los alumnos.

The lesson could be narrowed down when the concepts are introduced and the time allotted for students' comments could be shorter.

Although the teachers were not mentioned explicitly, students were critical of teachers, as this type of perception was usually evoked rather than stated explicitly.

Time was also evaluated negatively [10] in terms of the Duration of the lessons (30,12\%), the Frequency of the meetings $(6,2.5 \%)$ or the Length of the course $(6,2.5 \%)$.

[10][CB. St6. Q28.] [Algo para mejorar es] Más horas de cursada, ya que algunos temas y actividades que debíamos hacer en la misma no llegaron a concretarse.

[Something to be improved is] More hours of class, because some topics and activities we had to do could not be completed.

It seems that even when all the main contents of the course and activities were developed in class, students would have liked to spend more time on them. Some comments related to Time were connected to students' desire to do more language practise. Moreover, students identified lack of time as something to be improved more frequently in end-of-course surveys, once they were able to look back into the course-experience as a whole. This is relevant information in the planning of courses, as time should not be a factor to be underestimated for EFL language exercises.

A final comment needs to be made in connection with the findings presented so far and R2LP. First, it should be noted that no direct negative assessments were made of the stages proper to this Pedagogy such as Detailed Reading or Joint Writing. Only one student assessed the way in which a discussion was carried out, mainly in terms of order and chaos. Negative evaluations on Activities were oriented to how much time was spent on them or the ways in which they were carried out, evoking negative appraisal on teachers. This means that EFL teachers need to plan enough time to provide students with as much linguistic input as possible and create opportunities for practice. Additionally, although these students were competent readers and disciplinary experts, the negative perception of themselves and their linguistic abilities, language resources seem to be highly valued and quite a large amount of energy should be spent on them.

\subsection{Positive assessment}

Overall, students assessed the course positively more frequently than negatively. Among the most frequent entities, students mentioned the Lesson and its components (517 instances, which corresponds to $74 \%$ of the mentions), Participants $(67,9.5 \%)$, the Course $(44,6 \%)$, Writing $(31,4.5 \%)$, Time $(17,2.5 \%)$, 
students' Learning $(17,2.5 \%)$ and the Evaluation (3, $0.5 \%$ ) (Table 3).

Table 3. Entities appraised positively

\begin{tabular}{|c|c|c|c|c|c|}
\hline \multicolumn{3}{|c|}{ Entity } & $\begin{array}{l}\text { Class } \\
\text { surveys }\end{array}$ & $\begin{array}{l}\text { End-of- } \\
\text { course } \\
\text { surveys }\end{array}$ & Total \\
\hline \multirow{14}{*}{ Lesson } & \multirow{9}{*}{ Activities } & $\begin{array}{l}\text { Joint } \\
\text { writing }\end{array}$ & 46 & 7 & 53 \\
\hline & & In general & 38 & & 38 \\
\hline & & $\begin{array}{l}\text { Detailed } \\
\text { reading* }\end{array}$ & 28 & 9 & 37 \\
\hline & & Discussions & 36 & & 36 \\
\hline & & $\begin{array}{l}\text { Semantic } \\
\text { sensitivity }\end{array}$ & 23 & 11 & 34 \\
\hline & & $\begin{array}{l}\text { Grammar } \\
\text { practice }\end{array}$ & 23 & 10 & 33 \\
\hline & & $\begin{array}{l}\text { Pair or } \\
\text { group } \\
\text { activities }\end{array}$ & 17 & 1 & 18 \\
\hline & & $\begin{array}{l}\text { Theoretical } \\
\text { explanation }\end{array}$ & 10 & & 10 \\
\hline & & Total & 221 & 38 & 259 \\
\hline & \multicolumn{2}{|l|}{ Contents } & 83 & 28 & 111 \\
\hline & \multicolumn{2}{|l|}{ Materials } & 46 & 32 & 78 \\
\hline & \multicolumn{2}{|c|}{ As a whole } & 66 & 2 & 68 \\
\hline & \multicolumn{2}{|l|}{ Objectives } & & 1 & 1 \\
\hline & & Total & 416 & 101 & 517 \\
\hline \multirow{3}{*}{ Participants } & \multicolumn{2}{|l|}{ Students } & 11 & 12 & 23 \\
\hline & \multicolumn{2}{|l|}{ Teachers } & 6 & 38 & 44 \\
\hline & & Total & 17 & 50 & 67 \\
\hline Course & & Total & 25 & 19 & 44 \\
\hline \multirow{3}{*}{ Writing } & \multicolumn{2}{|l|}{ Product } & 11 & 8 & 19 \\
\hline & \multicolumn{2}{|l|}{ Process } & 8 & 4 & 12 \\
\hline & & Total & 19 & 12 & 31 \\
\hline \multirow{3}{*}{ Time } & \multicolumn{2}{|c|}{ Duration of the course } & & 16 & 16 \\
\hline & \multicolumn{2}{|c|}{$\begin{array}{l}\text { Frequency of } \\
\text { meetings }\end{array}$} & & 1 & 1 \\
\hline & & Total & & 17 & 17 \\
\hline Learning & & Total & 10 & 7 & 17 \\
\hline \multirow[t]{2}{*}{ Evaluation } & & & & 3 & 3 \\
\hline & \multicolumn{2}{|l|}{ Total } & 487 & 209 & 696 \\
\hline
\end{tabular}

*activities proposed by R2LP

Source: Author's own elaboration.

Students assessed the Lesson more frequently than any other element, which is in agreement with previous findings (CAVALCANTI, 2016). Within this category, "Activities" was mentioned 259 times, which corresponds to $37 \%$ of the total of entities, and to $50 \%$ of the Lesson. Thus, it is worth looking deeper into which activities students considered "useful", "clear", "interesting" and even "entertaining". Activities proposed by the R2LP were mentioned 90 times (17.5\% of the Lesson) (53 for Joint writing and 37 for Detailed reading), Activities in general 38 (7\%), Discussions $36(7 \%)$, activities that developed Semantic sensitivity 34 (6.5\%) and those which fostered Grammar practice 33 (6\%), followed by Pair/group activities and Theoretical explanations, with $18(3.5 \%)$ and 10 mentions (2\%), respectively.

Looking into activities that the R2LP proposes, both Joint writing and Detailed reading were perceived as useful to improve students' writing. Teacher-student Joint writing was the activity most frequently mentioned [11].

[11][CA. St21. Q2. C5.] Lo mejor de la clase fue la escritura en conjunto de la introducción utilizando el "esqueleto" propuesto. Porque demostró cómo construir la introducción que es una de la mayor dificultad al escribir un paper.

The best of the lesson was jointly writing the introduction using the "skeleton" proposed. Because it showed how to construct an introduction which is one of the most difficult sections when writing a paper.

The student states that the "best" of the lesson was the joint writing of the introduction. The reason she provides is that this activity served as an example on the writing of this stage, which represents a real challenge for writers. In the same line, and in agreement with other findings (SILVA, 2019), in [12], the student mentions that Joint writing has contributed to establishing a basis on which to build future writing.

[12] [CB. St18. Q16.] [Una actividad particularmente útil] Las actividades de escritura conjunta en las que se nos daba un modelo para completar, ya que sirve para practicar y da base para futuras producciones, hasta que uno haya adquirido entrenamiento y pulido sus errores más comunes.

[An activity that was particularly useful was] The activities of joint writing in which we were given an example to complete, because it serves for practicing and provides a basis for future writing, until we have acquired training and polished our most frequent mistakes. 
Joint writing seems to foster students' confidence since they rehearse their skills in the classroom. Teachers accompanying researchers in writing may appear to be an unnecessary -or even "intrusive"- task to carry out considering their achieved degree of expertise in their own fields. However, practicing with the teacher in a scaffold manner seems to be useful for them, especially considering that they use English as a foreign language in the writing of a highly contested genre such as the SRA. Apart from Joint writing, Detailed reading also proved to be positive for students [13].

[13] [CA. St20. Q2. C2.] [Una actividad útil fue] El análisis de las estructuras de los títulos y los abstracts. Permite entender en parte las observaciones que realizan los correctores.

[A useful activity was] The analysis of the structure of titles and abstracts. This allowed me to partially understand the corrections that reviewers make.

In this case, Detailed reading helped the student to realise what reviewers meant as he received feedback on his papers. Linguistic awareness appears to have contributed to a better understanding of social practices in the publication process. Similarly, in [14], the possibility to analyse text samples seems to have fostered genre awareness in the student, as he now can observe how effective writers achieve their aims.

[14] [CB. St23. Q16.] [Una actividad útil fue] Con el análisis de ejemplos yo pude ver como escribían los demás (autores de artículos bien hechos) y darme cuenta en qué fallaba yo.

[A useful activity was] With the analysis of examples, I could see how others write (authors of well written articles) and I could realise in which aspects I was failing.

Through text analysis in Detailed reading, the student states that he has been able to identify aspects in which he was failing, especially in comparison with the "authors of well written articles". It seems that analysing good text samples and observing how other people write contributed to his awareness of what to improve in his own writing.

In agreement with previous research (HUMPHREY; MACNAUGHT, 2011), teachers accompanying and guiding students in Joint construction into the intricacies of sample texts has been productive for students. Similarly, Detailed reading is an activity that was carried out by the teacher guiding and accompanying students, asking questions and leading them into becoming aware of text structure and functions. It has also helped them become more critical of the texts they read and write. These positive perceptions are in agreement with other pieces of research (MOYANO, 2011; 2013; HUMPHREY; MACNAUGHT, 2011) which show that joint deconstruction activities as proposed by the R2LP enable students to reflect upon language and context. In Detailed reading, students become more aware of the linguistic resources that they need for specific social purposes of texts (DE OLIVEIRA; LAN, 2014), while Joint writing scaffolds their writing process.

Also related to the Activities carried out, students found Discussions useful, which involved their participation as they shared their experiences related to writing, language, EFL, and the process of publication.

[15][CA. St 23. Q2] Me sirvió mucho escuchar a los demás, las distintas experiencias me ayudan a ampliar mi conocimiento sobre escritura dentro de la investigación.

Listening to the others was really helpful, the different experiences help me widen my knowledge about writing in the research activity.

In [15], the student values class discussions positively, as he states that listening to perspectives of others contributed to building his knowledge on writing. Some of them even mentioned it felt comforting to know that the hardships of writing was a shared common feeling and not just an individual adversity. In the case of [16], the student mentions the development of semantic sensitivity as one of the best activities.

[16] [CB. St12. Q16.] [Mencione una actividad útil] Las actividades para elegir los verbos adecuados para mitigar o dar énfasis a ciertas cosas. El uso de los artículos. Cuándo va The, $A / A n$ o no va nada. El uso de los tiempos verbales y la impersonalidad dependiendo de la sección. Me resultaron efectivas porque me hicieron poder ver las cosas desde otro punto de vista. Tal vez si no hubiera hecho el curso, o no las hubiera 
notado o no sabría la razón de por qué se usan.

[15] [Mention an activity which was useful] The activities in which we chose the appropriate verbs to mitigate or emphasize some things. The use of articles. When we should use the, a/an or nothing. The use of tenses and impersonality depending on the section. I though these were effective because I could see things from a different point of view. Maybe if I hadn't attended the course, I wouldn't have noticed them or I wouldn't know the reason why they are used.

The student refers to grammar practice and activities which develop semantic sensitivity, such as deciding how strong and specific different epistemic verbs were. They proved to be effective since -in the student's own words- she would not have realised why some tenses are used instead of others. Although developing semantic sensitivity is not strictly part of the R2LP, this type of activity is in agreement with SFL principles, since within a semantic perspective of language, it is desirable that students become aware of subtle differences in meanings as they become realised lexicogrammatically.

Thus far, we have devoted this analysis to the Lesson. In relation to other components students assessed, we would like to refer to Contents [17].

[17][CA. St19. Q8. C2.] Me gustó que se dieran todos esos tips que a veces uno no tiene en cuenta al momento de escribir como por ejemplo las palabras a no incluir.

I liked that teachers provided all those tips that you sometimes don't realise about when you write such as what words not to include.

Students favoured descriptions of grammar usage and assessed "rules of writing" positively. These were recommendations about language use in scientific writing, such as words that need to be avoided due to negative transfer, or pieces of advice such as using clear epistemic verbs in the statement of the purpose. It seems that guidelines for language use are valued since English is the subject students were struggling with. It also is interesting to notice that linguistic contents were frequently assessed both negatively as well as positively. A possible explanation to this apparent contradiction may be that although students found some difficulties in solving language exercises, extensive practice contributed to completing their gap in knowledge. Since researchers took the course to improve their writing in EFL, it is quite natural that they found language contents both hard to process but nonetheless useful to incorporate.

Shortly, the most frequently evaluated entity is the Lesson, and within this category, Activities were the most recurrent one, as Joint writing together with Detailed reading outnumber any other activity. The fact that these tasks were evaluated positively may be related to the fact that we purposefully incorporated R2LP activities in the course in order to assess them. Nevertheless, these were frequently viewed as positive by students even when they might have received a negative assessment. This evaluation makes them highly recommendable to be incorporated with adults for scientific writing in EFL contexts. Although teacherguided activities might be thought to mine students' autonomy -especially considering that students in this course were adult disciplinary experts- they were nonetheless found to be useful. Detailed reading has contributed to increasing students' awareness of SRA genre structure and recurrent lexicogrammatical realisations, while Joint writing seems to build their confidence as they are gradually "walked through" the process of writing (HUMPHREY; MACNAUGHT, 2011; WINGATE, 2012). It can be concluded that teacher accompaniment is desirable when learning scientific writing, even for a highly specialised audience like the one in this study. Students' overall positive perceptions of the genre-based course in general, as well as of tasks proposed by the R2LP in particular, pose further evidence to support the effectiveness of genre-based academic writing (CAVALCANTI, 2016; DE OLIVERA; LAN, 2014; HYLAND, 2003; SILVA, 2019; WINGATE, 2012).

6.

Final considerations

This work reports the assessment that a group of researchers in their role of students made on an 
R2LP-based writing course. Students' opinions were collected through class and end-of-course surveys, which were analysed in terms of Attitude and the entities to which evaluative language referred. Special attention was paid to how students viewed activities proposed by the R2LP.

A limitation of this study is that it reports students' reaction to the application of the R2LP, thus there is no causal relationship between the implementation of the course, students' perceived usefulness and students' actual improved writing. Other sources of data, such as the linguistic description of students' productions may represent further indicators of the efficacy of this genre pedagogy. Moreover, other data collection techniques on students' perceptions such as in-depth interviews (SHEHADEH, 2011) may contribute to deepen the interpretations of the data in the surveys. Additionally, another limitation of this study is the impossibility to compare, for example, students' perceptions of other genre-based approaches with the teaching of EAP and ESP. Since the group of students who took part in this study had received training in English mainly for general purposes, the genre methodology used might have appeared to them as totally innovative and useful in their limited view of other teaching possibilities.

In spite of these drawbacks, our findings suggest that the implementation of writing courses with an obvious leading role of the teacher as the language expert seems to be appropriate in the teaching of English in postgraduate courses, where students usually need to publish an SRA as an institutional requirement to obtain their Ph.D. degrees (WINGATE, 2012).

Students' perceptions contribute to the assessment of the R2LP methodology from the point of view of highly qualified participants. Our results suggest that it is worthwhile to teach genre-based scientific writing courses, with a focus on Detailed reading and on the frequent and typical lexicogrammatical realisations of the genre at stake. Teacher-guided Joint writing activities are also highly recommended to be incorporated as regular practices in courses like the one presented here. This is particularly appropriate in connection to English, an area of knowledge in which researchers are not experts and feel insecure of, but still need to learn about to be able to publish internationally. Since in our course Joint writing needed to be carried out in connection to a general topic which students from a variety of disciplines could contribute to, an interesting line of inquiry for further research may be to assess the extent to which this task enhances students' writing dealing with more specific disciplinary topics closely related to students' research expertise. It might be necessary to make a longitudinal study, with few students or individually, in order to register detailed perceptions that occur during this interaction.

Although this study was carried out in one institution and findings are presented through the lens of a limited number of participants, the overall positive assessment of both the R2LP and other components of the lesson evidence the need for institutional actions that systematically incorporate the teaching of English for academic purposes as part of graduate and postgraduate courses (MARTíNEZ, 2011) which emphasise teachers' leading roles in the coconstruction of knowledge. With the increasing need of Latin American researchers to publish in English, it is essential that future work capitalises on training opportunities, specific materials and genre pedagogies that aim at mastering the texts which are required by researchers to actively participate in the scientific community. It is clear that investigators face the vital necessity to be provided with resources that enable them to write scientific texts in EFL, and, in view of our findings, the R2LP represents an appropriate approach to do so.

\section{Referências}

MIRALLAS (in press)

BAKHTIN, Mikhail. The Dialogic Imagination: Four Essays. Austin: University of Texas Press, 1981. 444 p. BALLARD, Tom; BECKER, Kimberly; SMITH, Jordan. The words with which we reflect: A study of the language used in student ePortfolios. In: Panel presentation at the Computers and Writing Conference, 2017, Findlay, $\mathrm{OH}$.

BANEGAS, Darío Luis. Learning subject-specific content through ESP in a Geography teaching programme: An action research story in Argentina. English for Specific 
Purposes, v. 50, p. 1-13, 2018.

https://doi.org/10.1016/j.esp.2017.11.001

BEDNAREK, Monika. Emotion talk across corpora. Basingtoke: Palgrave Macmillan, 2008. 242 p. doi:10.1057/9780230285712

BHATIA, Vijay. Genre-mixing in academic introductions. English for Specific Purposes, v. 16, n. 3, p. 181-195, 1997. https://doi.org/10.1016/S0889-4906(96)00039-7

BITCHENER, John; BASTURKMEN, Helen. Perceptions of the difficulties of postgraduate $\mathrm{L} 2$ thesis students writing the discussion section. Journal of English for Academic Purposes, v. 5, n. 1, p. 4-18, 2006. https://doi.org/10.1016/j.jeap.2005.10.002

BRAGA, Corina Furtado. Produção escrita no ensino/aprendizagem de inglês como língua estrangeira no contexto de uma escola particular de Natal, RN: uma pesquisa-ação em pedagogia do gênero. 2019. 229 f. Dissertação para a obtenção do título de Mestre. Universidade Federal do Rio Grande do Norte, Natal, Rio Grande do Norte,

Brasil. https://repositorio.ufrn.br/jspui/handle/123456789/ 28397

BRISK, María Estela. Engaging students in academic literacies: Genre-based pedagogy for K-5 classrooms. New York: Routledge, 2014. 380 p.

BRUCE, lan. Results sections in sociology and organic chemistry articles: A genre analysis. English for Specific Purposes, v. 28, n. 2, p. 105-124, 2009. https://doi.org/10.1016/j.esp.2008.12.005

CARLINO, Paula. Escribir a través del currículum: tres modelos para hacerlo en la universidad. Lectura $Y$ Vida, v. 25, n. 1, p. 16-27, 2004.

CAVALCANTI, Beatriz Alves Paulo. A pedagogia de gêneros da Escola de Sydney en aulas de Inglês para Fins Específicos: um voo sistêmico-funcional. 2016. 206 f. Dissertação para a obtenção do título de Doutor. Universidade Federal do Rio Grande do Norte, Natal, Rio Grande do Norte,

Brasil. https://repositorio.ufrn.br/jspui/handle/123456789/ 21603

CARLINO, Paula. Reading and writing in the social sciences in Argentine universities. In BAZERMAN, Charles; KRUT, Robert; LUNSFORD, Karen; MCLEOD, Susan; NULL, Suzie; ROGERS, Paul; STANSELL, Amanda (Edits.), Traditions of Writing Research. New York: Routledge. 2009. 448 p. p. 283-296.

CHRISTIE, Frances. Language education throughout the school years: A functional perspective. Malden, MA: Wiley-Blackwell, 2012. p. 260.

DE OLIVEIRA, Luciana; LAN, Shu-Wen. Writing science in an upper elementary classroom: A genre-based approach to teaching English language learners. Journal of Second Language Writing, v. 25, p. 23-39, 2014. doi:10.1016/j.jslw.2014.05.001

DEREWIANKA, Beverly; JONES, Pauline. Teaching Language in Context. Melbourne: Oxford University Press, 2012. $368 \mathrm{p}$.

ESPINOZA, Ana María. Contrastive analysis of the Spanish and English passive voice in scientific prose. English for Specific Purposes, v. 16, n. 3, p. 229-243, 1997. https://doi.org/10.1016/S0889-4906(96)00034-8
GONZÁLEZ RODRÍGUEZ, María José. La expresión lingüística de la actitud en el género de opinión: el modelo de la valoración. RLA. Revista de Lingüística

Teórica y Aplicada, v. 49, n. 1, p. 109-141, 2011. https://doi.org/10.4067/s0718-48832011000100006

HAGGAN, Madeline. Research paper titles in literature, linguistics and science: dimensions of attraction. Journal of Pragmatics, v. 36, n. 2, p. 293-317, 2004.

HALLIDAY, Michael Alexander Kirkwood. Language as social semiotic. The social interpretation of language and meaning. London: Arnold, 1978. 256 p.

HALLIDAY, Michael Alexander Kirkwood; MARTIN, James Robert. Writing Science: Literacy and Discursive Power. London: The Falmer Press, 1993. 309 p.

HALLIDAY, Michael Alexander Kirkwood; MATTHIESSEN, Christian (2014). An Introduction to Functional Grammar (4 ed.). London: Arnold, 2014. 786 p.

HERAZO RIVERA, José David; SAGRE BARBOZA Anamaría. The Co-Construction of Participation Through Oral Mediation in the EFL Classroom. PROFILE Issues in Teachers' Professional Development, v. 18, n. 1, p. 149-163, 2016. https://doi.org/10.15446/profile.v18n1.49948

HERRERO RIVAS, Luz Elena. Actitud asociada a tipos de cláusulas en textos de historia. Un análisis desde la teoría de la valoración. Ikala, v. 22, v. 2, p. 221-236, 2017. https://doi.org/10.17533/udea.ikala.v22n02a04

HOLMES, Richard. Genre analysis, and the social sciences: An investigation of the structure of research article discussion sections in three disciplines. English for Specific Purposes, v. 16, n. 4, p. 321-337, 1997. https://doi.org/10.1016/S0889-4906(96)00038-5

HOOD, Susan. The persuasive power of prosodies: Radiating values in academic writing. Journal of English for Academic Purposes, v. 5, n. 1, p. 37-49, 2006. doi:10.1016/j.jeap.2005.11.001

HOOD, Susan. Appraising research: Evaluation in Academic writing. UK: Palgrave Macmillan, 2010. 226 p.

HOOD, Susan; MARTIN, James Robert. Invocación de actitudes: El juego de la gradación de la valoración en el discurso. Revista Signos, v. 38, n. 58, p. 195-220, 2005. https://doi.org/10.4067/s0718-09342005000200004

HOPKINS, Andy; DUDLEY-EVANS, Tony. A genrebased investigation of the discussion sections in articles and dissertations. English for Specific Purposes, v. 7, n. 2, p. 113-121, 1988. https://doi.org/10.1016/0889. 4906(88)90029-4

HUANG, Ju Chuan. Learning to write for publication in English through genre-based pedagogy: A case in Taiwan. System, v. 45, n. 1, p. 175-186, 2014. https://doi.org/10.1016/j.system.2014.05.010

HUFFMAN, Sarah. Exploring learner perceptions of and interaction behaviors using the Research Writing Tutor for research article Introduction section draft analysis. 2015. $498 \mathrm{f}$. Tese de doutorado. Iowa State University, Ames, lowa. https://lib.dr.iastate.edu/etd/14418/

HUMPHREY, Sally; MACNAUGHT, Lucy. Revisiting Joint Construction in the tertiary context. Australian Journal of Language and Literacy, v. 34, n. 1, p. 98-116, 2011. 
HUMPHREY, Sally; MACNAUGHT, Lucy. Functional language instruction and the writing growth of English language learners in the middle years. TESOL Quarterly, v. 50 , n. 4 , p. $792-816$, 2016. doi:10.1002/tesq. 247

HYLAND, Ken. Academic attribution: Citation and the construction of disciplinary knowledge. Applied Linguistics, v. 20, n. 3, p. 341-367, 1997. https://doi.org/10.1093/applin/20.3.341

HYLAND, Ken. Genre-based pedagogies: A social response to process. Journal of Second Language Writing, v. 12, n. 1, p. 17-29, 2003.

https://doi.org/10.1016/S1060-3743(02)00124-8

HYLAND, Ken; TSE, Polly. Hooking the reader: A corpus study of evaluative that in abstracts. English for Specific Purposes, v. 24, n. 2, p. 123-139, 2005. doi:10.1016/j.esp.2004.02.002

HYON, Sunny. Genre in three traditions: Implications for ESL. TESOL Quarterly, v. 30, n. 4, p. 693-722, 1996. doi:10.2307/3587930

KRISTEVA, Julia. Desire in Language. A Semiotic Approach to Literature and Art. Oxford: Blackwell, 1980. $305 \mathrm{p}$.

LEMKE, Jay. Talking science: Language, learning, and values. Norwood, NJ: Ablex Publishing, 1990. 264 p.

LEMKE, Jay . Multiplying meaning: Visual and verbal semiotics in scientific text. In: MARTIN, James Robert \& VEEL, Robert (Edits.). Reading Science: critical and functional perspectives. London: Routledge, 1998. 384 p. p. 87-113.

LIM, Jason Miin-Hwa. Writing descriptions of experimental procedures in language education: Implications for the teaching of English for academic purposes. English for Specific Purposes, v. 47, p. 61-80, 2017. https://doi.org/10.1016/j.esp.2017.05.001

MANCHÓN, Rosa; DE HAAN, Pieter. Writing in foreign language contexts: An introduction. Journal of Second Language Writing, v. 17, n. 1, p. 1-6, 2008. https://doi.org/10.1016/j.jslw.2007.08.002

MARTIN, James Robert. Technicality and abstraction: language for the creation of specialised texts. In: CHRISTIE, Frances (Edit.). Writing in schools: reader. Geelong: Deakin University Press, 1989. p. 36-44.

MARTIN, James Robert. English text: System and structure. Amsterdam: John Benjamins, 1992. 634 p.

MARTIN, James Robert. Discourses of science: Recontextualisation, genesis, intertextuality and hegemony. In: MARTIN, James Robert; VEEL, Robert (Edits.), Reading science: Critical and functional perspectives on Discourses of Science. London: Routledge, 1998. 389 p. p. 3-14.

MARTIN, James Robert. Mentoring semogenesis: "Genre-based" literacy pedagogy. In: CHRISTIE, Frances (Ed.). Pedagogy and the Shaping of Consciousness: Linguistic and social processes. London: Cassell, 1999. 308 p. p. $123-155$.

MARTIN, James Robert. Genre and language learning: A social semiotic perspective. Linguistics and Education, v. 20, n. 1, p. 10-21, 2009.

MARTIN, James Robert; ROSE, David. Genre relations: Mapping culture. London: Equinox, 2008. 253 p.
MARTIN, James Robert; WHITE, Peter. The language of evaluation: Appraisal in English. London: Palgrave, 2005. $278 \mathrm{p}$.

MARTÍNEZ, Iliana. Impersonality in the research article as revealed by analysis of the transitivity structure. English for Specific Purposes, v. 20, n. 3, p. 227-247, 2001. https://doi.org/10.1016/S0889-4906(00)00013-2

MARTÍNEZ, Iliana. Capitalizing on the advantages of the Latin American EAP situation: Using authentic and specific materials in EAP writing instruction. Iberica, $v$. 21, n. 21, p. 31-48, 2011.

MOYANO, Estela Inés. Una propuesta para la enseñanza de la lectura y la escritura basada en la teoría de género y registro de la LSF: resultados de una investigación e implementación en diferentes niveles educativos. In: /l Conferencia Latinoamericana de Lingüística Sistémico-Funcional. ALSFAL, 2005, Concepción, Chile, Facultad de Educación de la Universidad Católica de la Santísima Concepción. p. 1 16.

MOYANO, Estela Inés. Enseñanza de la lectura y la escritura basada en la teoría de género y registro de la LSF: resultados de una investigación. Revista Signos, v. 40 , n. 65 , p. 573-608, 2007. doi:10.4067/S071809342007000300009

MOYANO, Estela Inés. Deconstrucción y Edición Conjuntas en la enseñanza de la escritura: La reflexión sobre género y discurso en la formación académica y profesional. In: VI SIGET, 2011, Lagoa Nova, Natal: Universidade Federal do Rio Grande do Norte. Anais VI Simpósio Internacional de Estudios de Gêneros Textuais. (pp. 1-26).

MOYANO, Estela Inés. Aprender ciencias y humanidades: una cuestión de lectura y escritura. Aportes para la construcción de un programa de inclusión social a través de la educación lingüística. Buenos Aires: Universidad Nacional de General Sarmiento, 2013. 434 p.

MOYANO, Estela Inés. La enseñanza de la lectura y la escritura académicas mediante programas a lo largo del curriculum universitario: opción teórica, didáctica y de gestión. DELTA, v. 34, n. 1, p. 235-267. 2018. doi:10.1590/0102-445074896274115057

O'DONNELL, Michael (2008). The UAM CorpusTool: Software for corpus annotation and exploration. In: BRETONES CALLEJAS, Carmen; FERNÁNDEZ SÁNCHEZ, José Francisco; IBÁÑEZ IBÁÑEZ, José Ramón; GARCÍA SÁNCHEZ, María Elena; CORTÉS DE LOS RÍOS, María Enriqueta; SALABERRI RAMIRO, Sagrario ... CANTIZANO MÁRQUEZ, Blasina (Edits.), Applied Linguistics Now: Understanding Language and Mind. Almería: Universidad de Almería, 1915. p. p. 14331447.

OTEÍZA, Teresa; PINUER, Claudio. Prosodia valorativa: construcción de eventos y procesos en el discurso de la. Discurso \& Sociedad, v. 6, n. 2, p. 418-446, 2012.

PARKINSON, Jean. The Discussion section as argument: The language used to prove knowledge claims. English for Specific Purposes, v. 30, n. 3, p. 164175, 2011. https://doi.org/10.1016/j.esp.2011.03.001

PASCUAL, Mariana. La asociación de recursos de valoración: El caso de las organizaciones de derechos 
humanos en la prensa escrita Argentina. Onomazein, v. 30, n. 2, p. 99-114, 2014.

https://doi.org/10.7764/onomazein.alsfal.8

PASCUAL, Mariana. La violación a los derechos humanos en la Argentina: dinámica de dos décadas de representación en medios. Discurso y Sociedad, v. 11, n. 3, p. 388-413, 2017.

PASCUAL, Mariana. La construcción de la evaluación en los discursos de memoria y dolor: aportes desde las intersecciones. In: LONDOÑO ZAPATA, Oscar Iván, OLAVE ARIAS, Giohanny (Coords.). 2019. Métodos de Análisis del Discurso: Perspectivas Argentinas. 296. p. p. 177-194.

RAMOS, Kathleen. Teaching adolescent ELs to write academic-style persuasive essays. Journal of Adolescent \& Adult Literacy, v. 57, n. 8, p. 655-665, 2014. doi:doi.org/10.1002/jaal.303

ROSE, David. Science discourse and industrial hierarchy. In: MARTIN, James Robert \& VEEL, Robert. Reading science: Critical and functional perspectives on discourses of science. London: Routledge, 1998. 389 p. p. 236-265.

ROSE, David; MARTIN, James Robert (2012). Learning to write/Reading to learn. UK: Equinox Publishing, 2012. $256 \mathrm{p}$.

ROTHERY, Joan. Learning about language. In: HASAN, Ruqaiya; MARTIN, James Robert (Edits.). Language development: Learning language, learning culture. Norwood, NJ: Ablex, 1989. p. 199-256.

ROTHERY, Joan. Making changes: Developing an educational linguistics. In: HASAN, Ruqaiya \&

WILLIAMS, Geoffrey (Edits.). Literacy in society. London: Longman, 1996. p. 86-123.

RUIYING, Yang; ALLISON, Desmond. Research articles in applied linguistics: Moving from results to conclusions. English for Specific Purposes, v. 22, n. 4, p. 365-385, 2003. https://doi.org/10.1016/S0889-4906(02)00026-1

SALAGER-MEYER, Françoise. A text-type and move analysis study of verb tense and modality distribution in medical English abstracts. English for Specific Purposes, v. 11, n. 2 , p. 93-113, 1992. doi:10.1016/S08894906(05)80002-X

SAMRAJ, Betty. An exploration of a genre set: Research article abstracts and introductions in two disciplines. English for Specific Purposes, v. 24, n. 2, p. 141-156, 2005. doi:10.1016/j.esp.2002.10.001

SAN MARTíN, Gimena; HELALE, Gabriela; FALETTI, Paula. Elementos valorativos en el discurso de la observación de clase. In: VIII ALSFAL, 2012, Montevideo, Uruguay. p. 205-213.

SELINKER, Larry. On the use of informants in Discourse Analysis and 'Language for Specialized Purposes'. International Review of Applied Linguistics in Language Teaching, v. 17, n. 1, p. 189-216, 1979.

SHEHADEH, Ali. Effects and student perceptions of collaborative writing in L2. Journal of Second Language Writing, v. 20, n. 4, p. 286-305, 2011. https://doi.org/10.1016/j.jslw.2011.05.010

SILVA, Lúcia de Fátima Medeiros. Pedagogia de gênero no ensino da língua inglesa como língua adicio-nal: pesquisa-ação no ensino fundamental da rede pública no $R N$. 2019. Dissertação para a obtenção do título de Mestre. Universidade Federal do Rio Grande do Norte, Natal, Rio Grande do Norte,

Brasil. https://repositorio.ufrn.br/jspui/handle/123456789/ 27966

SOLER, Viviana. Comparative and contrastive observations on scientific titles written in English and Spanish. English for Specific Purposes, v. 30, n. 2, p. 124-137, 2011.

STORCH, Neomy. Collaborative writing: Product, process, and students' reflections. Journal of Second Language Writing, v. 14, n. 3, p. 153-173, 2005. https://doi.org/10.1016/j.jslw.2005.05.002

SWALES, John. Genre analysis: English in academic and research settings. Glasgow: Cambridge University Press, 1990. p. 288.

SWALES, John. Worlds of Genre-Metaphors of Genre. In: BAZERMAN, Charles; BONINI, Adair; FIGUEIREDO, Débora (Eds.). Genre in a changing world. Colorado: Parlor Press, 2009. 504 p. p. 3-16.

TARDY, Christine. Researching first and second language genre learning: A comparative review and a look ahead. Journal of Second Language Writing, v. 15, n. 2, p. 79-101, 2006.

https://doi.org/10.1016/j.jslw.2006.04.003

THETELA, Puleng. Evaluated entities and parameters of value in academic research articles. English for Specific Purposes, v. 16, n. 2, p. 101-118, 1997. https://doi.org/10.1016/s0889-4906(96)00022-1

THOMPSON, Dorothea. Arguing for Experimental "Facts" in Science: A Study of Research Article Results Sections in Biochemistry. Written Communication, v. 10, n. 1, p. 106-128, 1993.

https://doi.org/10.1177/0741088393010001004

TROYAN, Francis. Learning to Mean in Spanish Writing: A Case Study of a Genre-Based Pedagogy for Standards-Based Writing Instruction. Foreign Language Annals, v. 49, n. 2, p. 317-335, 2016. https://doi.org/10.1111/flan.12192

WHITE, Peter. Telling media tales. The news story as rhetoric. 1998. 440 f. Tese de doutorado. University of Sydney, Sydney, Australia.

WIGNELL, Peter. Making The Abstract Technical: on the evolution of the discourse of social science. 1997. Tese de doutorado: University of Sydney.

WILLIAMS, Ian. Results sections of medical research articles: Analysis of rhetorical categories for pedagogical purposes. English for Specific Purposes, v. 18, n. 4, p. 347-366, 1999.

WINGATE, Ursula. Using Academic Literacies and genre-based models for academic writing instruction: $A$ "literacy" journey. Journal of English for Academic Purposes, v. 11, n. 1, p. 26-37, 2012. https://doi.org/10.1016/j.jeap.2011.11.006 
MIRALLAS, Carolina Andrea. Students' perceptions of a scientific writing course: SFL Genre Pedagogy in an EFL context. Signo, Santa Cruz do Sul, v. 46, n. 86, maio 2021. ISSN 1982-2014. Disponível em: $<$ https://online.unisc.br/seer/index.php/signo/article/view/15900> doi:https://doi.org/10.17058/signo.v46i86.15900. 